УДК 373.24

\title{
ФОРМИРОВАНИЕ СЛОВАРЯ ИМЕН ПРИЛАГАТЕЛЬНЫХ У ДЕТЕЙ СТАРШЕГО ДОШКОЛЬНОГО ВОЗРАСТА С ОБЩИМ НЕДОРАЗВИТИЕМ РЕЧИ ПОСРЕДСТВОМ ИСПОЛЬЗОВАНИЯ СИСТЕМЫ ДИДАКТИЧЕСКИХ ИГР
}

\author{
Загоранская Зинаида Михайловна \\ ГУО «Ясли-сад № 19 г. Мозыря»
}

Аннотация: в статье освещены вопросы повышения эффективности формирования словаря имен прилагательных у детей с общим недоразвитием речи старшего дошкольного возраста. Идея состоит в использовании системы дидактических игр, направленных на увеличение объема словаря, активизацию словаря, уточнение структуры значения слова.

Ключевые слова: прилагательные, дошкольник, речь, нарушения, игры.

\section{FORMATION OF A DICTIONARY OF ADJECTIVES IN OLDER PRESCHOOL CHILDREN WITH GENERAL SPEECH UNDERDEVELOPMENT THROUGH THE USE OF A SYSTEM OF DIDACTIC GAMES}

\section{Zahoransky Zinaida Mixalovna}

\begin{abstract}
The article highlights the issues of improving the efficiency of forming a dictionary of adjectives in children with General speech underdevelopment of older preschool age. The idea is to use a system of didactic games. Aimed at increasing the volume of the dictionary, activating the dictionary, and clarifying the structure of the word meaning.
\end{abstract}

Key words: adjectives, preschooler, speech, violations, games.

Коммуникативная компетенция рассматривается как базисная характеристика личности ребенка дошкольного возраста, как важная предпосылка благополучия в социальном и интеллектуальном развитии ведущих видов деятельности. Формирование лексики детей с общим недоразвитием речи (далее ОНР), как одного из основных средств такой компетенции - задача, которую решает учитель-дефектолог. 
Освещенные в научно методической литературе вопросы формирования словаря детей с ОНР, многолетний собственный опыт работы с детьми данной категории (в специальной группе для детей с тяжелыми нарушениями речи в учреждении дошкольного образования) показывают, что дети, достигнув старшего дошкольного возраста при общей несформированности лексического строя, имеют значительно большее, чем у сверстников с нормальной речью преобладание предметного и глагольного словаря по отношению к другим частям речи. Наибольшие затруднения вызывает употребление имен прилагательных. У детей бедный словарный запас, наблюдается резкое расхождение между активным и пассивным словарем, затруднения при подборе антонимов, при группировке слов по семантическим признакам, затруднения в овладении навыками словообразования прилагательных. Отмечается неточность употребления слов, которая выражается в вербальных парафазиях, однотипность используемых имен прилагательных.

Описывая характерные особенности словаря детей с ОНР Р.И. Лалаева, Н.В. Серебрякова указывают на более значительное, чем в норме расхождение в объеме активного и пассивного словаря, неточностях употребляемых слов, которые выражаются в вербальных парафазиях. Замены прилагательных свидетельствуют о том, что дети не выделяют существенных признаков, не дифференцируют качество предметов. Распространенными являются, например, такие замены: высокий-длинный, низкий-маленький, узкиймаленький, узкий-тонкий, короткий-маленький, пушистый-мягкий. Замены прилагательных осуществляются из-за недифференцированности признаков величины, высоты, ширины, толщины. [1, с. 24].

Для выявления уровня сформированности словаря имен прилагательных у детей, в рамках логопедического обследования в начале 2019/2020 учебного года было проведено углубленное исследование состояния атрибутивной лексики. При разработке методики исследования использовались некоторые приемы и методы, описанные Р.И. Лалаевой [2, с 17]. Критерии, раскрывающие сформированность словаря, определены исходя из того, что планировалось формировать, выполняя программу Ю.Н. Кисляковой, Л.Н. Мороз «Воспитание и обучение детей с тяжелыми нарушениями речи» четвертого года обучения: объем активного словаря, объем пассивного словаря, группировка слов, подбор антонимов, образование сравнительной степени прилагательных, образование относительных прилагательных. Анализ результатов исследования, а также анализ речи воспитанников на занятиях и в 
свободной деятельности показал, что овладение атрибутивной лексикой представляет особую сложность. Дети не знают многих прилагательных, употребляющихся в речи их сверстников с нормальной речью (кислый, квадратный, аккуратный, и другие), испытывают затруднения в поиске известного слова. При подборе антонимов чаще всего используют те же слова с приставкой не (широкий - неширокий, хороший - нехороший). Характерная особенность словаря детей с ОНР - неточность употребления слов, которая выражается в вербальных парафазиях (высокий - большой, широкий большой, длинный - большой и других). Отмечается однотипность используемых имен прилагательных - на вопрос «Какой?» чаще всего называется цвет предмета, или, например, слово «красивый». Большую сложность для детей представляет словообразование прилагательных. Таким образом, нарушения формирования атрибутивной лексики у детей с ОНР проявляются в ограниченности словарного запаса, резком расхождении объема активного и пассивного словаря, своеобразии употребления слов.

Актуальность темы обусловлена тем, что даже в условиях целенаправленного педагогического процесса овладение словарем имен прилагательных для детей с ОНР представляет наибольшие трудности.

Все это указывает на необходимость поиска более эффективных средств коррекционно-педагогического воздействия при формировании словаря имен прилагательных у детей старшего дошкольного возраста с ОНР. Среди разнообразных методов на первый план выдвигается дидактическая игра, поскольку она является ведущим, всесторонне развивающим видом детской деятельности.

Исходя из отмеченных особенностей формирования словаря имен прилагательных у детей старшего дошкольного возраста с ОНР, определены направления работы:

- расширение объема словаря;

- активизация словаря;

- формирование и уточнение структуры значения слова.

Выделение этих направлений во многом является условным, так как в процессе формирования лексики они часто переплетаются, взаимодействуют.

При подборе необходимого игрового дидактического материала использовались игры, рекомендованные программой Ю. Н. Кисляковой, Л. Н. Мороз «Воспитание и обучение детей с тяжелыми нарушениями речи» [3, с 192], игры из пособий Ю.Н. Кисляковой, М.В. Былино [4, с.4]. Материал, 
предлагаемый Т.А. Ткаченко [5, с 30] был обработан и адаптирован таким образом, чтобы он стал доступными, занимательным и интересными для детей с ОНР. Результатом многолетнего труда явились авторские игры.

Дидактические игры систематизировались по указанным направлениям работы. Был изготовлен и приобретен необходимый дидактический материал, приведен в эстетический вид, создана его картотека.

Рекомендуемая область применения игрового дидактического материала - подгрупповые и индивидуальные занятия в группе для детей с тяжелыми нарушениями речи. При подготовке занятий по конкретной лексической теме из программы определяется словарь имен прилагательных для формирования у детей и выбираются игры, которые направлены на увеличение объема, активизацию словаря, формирование структуры значения слов. Формирование лексики осуществляется в тесной взаимосвязи с грамматическим строем речи, формированием правильного звукопроизношения, а также с развитием мыслительных операций (классификации, анализа, синтеза, обобщения).

Игры для расширения объема словаря имен прилагательных используются таким образом, чтобы у детей параллельно развивались представления о цвете, величине, форме, признаках высоты, толщины, а также формировались умения сравнивать предметы по различным признакам. Так, в придуманной автором игре «Обувь для клоунов» на занятии по теме «Одежда и обувь» сравнивая предметы обуви на парных картинках, дети определяют, что помимо цвета, обувь различается и по другому признаку предназначением для мужчин, женщин или детей. В словарь вводятся прилагательные «мужская», «женская», «детская». В игре «Такой же, как...», выбранной при изучении темы «Животные жарких стран», формируются определения: высокий, быстрый, сильный, забавный и другие. Учитывая то, что детям с ОНР тяжело подобрать нужное слово к определениям, не имея наглядной опоры, изготовлен макет для магнитной доски. Появилась возможность предъявлять игру в различных вариациях: объединять в группы, например, огромные животные, или, прикрепив рядом, например, жирафа и кенгуру предложить детям ответить, кто кого выше, кто кого быстрее.

Дети с ОНР плохо понимают значение абстрактных понятий, характеризующих человека, следовательно, и соответствующих слов в их словаре нет. Для устранения этого недостатка используется игра «Что это значит?». Вначале дети заканчивают предложение педагога: «Смелый человек, это когда он ... ». Затем предложение переделывается: «Если человек ничего 
не боится, значит, он ... ». Слова для примера: капризный, ленивый, жадный, честный, аккуратный, хитрый, послушный, вежливый.

Одним из основных средств обогащения атрибутивного словаря является овладение словообразованием прилагательных. В процессе использования игры «Из чего, какой?», целью которой является формирование навыков образования относительных прилагательных, выявилась проблема того, что дети, образовывая слова по аналогии, не понимают их значения. Данную проблему помогли решить разработанные и изготовленные альбомы: «Виды ткани, ее качество и изделия из нее», «Виды бумаги, ее качество и изделия из нее», «Изделия из глины», «Свойства пластмассы и изделия из нее», «Изделия из древесины», «Свойства стекла и изделия из него». Теперь упростилась задача подбора наглядного материала при знакомстве детей с предметами, изготовленными руками человека. Альбомы заинтересовали воспитанников, часто дети сами просят рассмотреть их и назвать стеклянные, пластмассовые, бумажные и иные изделия. Для устранения ошибок, которые дети допускают при словообразовании (кожавый, бумажливый и подобных) проводится работа по уточнению звукового образа слова.

Обучение детей навыкам образования сравнительной степени прилагательных (игра «Хороший, еще лучше») предваряется работой по формированию умений устанавливать сериационные ряды. Вначале используются различные геометрические фигуры, полоски, затем натуральные предметы, и наконец, игры типа «От самого короткого к самому длинному», «От самого маленького к самому большому». Чтобы дети соотносили изображения предметов с их реальными образами, в качестве пособий подбираются картинки одинакового размера. Использование детьми слов: «больше», «меньше», «ниже», «короче», «мягче» и других способствует также автоматизации правильного произношения звуков [Ш], [Ж], [Ч].

Следует отметить, что при определении последовательности логопедической работы по обогащению атрибутивного словаря, как и всей лексики в целом, учитывается частотность словаря детей старшего дошкольного возраста, степень сформированности звукопроизношения, а также последовательность изучения материала по программе для детей с тяжелыми нарушениями речи.

Для сокращения резкого расхождения активного и пассивного словаря подобраны игры, направленные на его активизацию. Активизация словаря это закрепление слова в контексте: в словосочетаниях, предложениях, тексте. 
Для разминки на занятиях разной тематики особую популярность у автора и его воспитанников приобрела игра «Каждый знает». Продолжая фразу педагога: «Каждый знает, что легким бывает» (огромным, кислым и других), дети называют подходящие предметы. Работая с предметными картинками в рамках определенной темы, используется игра «Подбери признак». Вслед за ней - «Сделай предложение длиннее» - по тем же картинкам педагог составляет предложение, дети распространяют его определением, подобранным словом-признаком. Целью игры «Что подходит?» является формирование умений подбирать синонимы. Из ряда определений дети выбирают те, которые подходят к предъявляемым изображениям: воин смелый, храбрый, трусливый; медведь - неуклюжий, ловкий, неповоротливый. Картинки и ряды определений подбираются в соответствии с изучаемой темой.

Не обошлось без авторских разработок. Для активного употребления прилагательных, обозначающих цвет предмета, в том числе и оттеночный, придумана игра «Карандаши», в ходе которой дети выбирают нужный карандаш для раскрашивания того, что «забыл» дорисовать художник. Наиболее удачной представляется игра «Определи, какой», предполагающая подбор и использование детьми по два определения к предмету. Так, предъявив детям карточку с изображением большого синего овала, большого желтого квадрата и маленького желтого квадрата, задается вопрос: «Определите фигуру, если она не маленькая и не желтая». Ответ детей: «Овал, эта фигура большая и синяя». Атрибутами игры, помимо картинок, могут служить муляжи, натуральные предметы - в зависимости от темы занятия.

Большую роль в активизации словаря признаков принадлежит загадке. Придумать загадку ребенку помогает разработанная схема «Составь загадку об игрушке». Работая по этой схеме, педагог формирует у детей умение использовать прилагательные, обозначающие размер, цвет, материал, из которого сделан предмет.

Трудности актуализации словаря у детей с ОНР обуславливает несформированность семантических полей. Для формирования у детей умений объединять слова по семантическим признакам, выделять слова из семантического поля подходит игра «Четвертый лишний». Из ряда слов дети определяют «лишнее»: круглый, квадратный, белый, овальный; красный, высокий, синий, желтый. Но данный вариант ее модернизации (словесная) вначале представляет трудности для воспитанников, потому что без 
наглядного образа используемые слова приобретают абстрактное значение. Поэтому перед применением игры рекомендуется проводить упражнения такого типа: «Назови, какого цвета предметы?», «Какой формы?», «Из какого материала сделаны?».

Игры для формирования и уточнения структуры значения слова помогают преодолеть неточности и парафазии при использовании некоторых прилагательных. Для указанной категории разработаны несколько игр, формирующих умения дифференцировать значения слов на основе признаков противопоставления, сходства, аналогии.

«Исправь ошибки» (огурцы синие, пол железный, морковь круглая, селедка кислая) - способствует, также, развитию у детей чувства юмора и вызывает адекватную эмоциональную реакцию - смех. «Что общее?» (елка и огурец, руль и колесо) - для игры можно подобрать пары картинок. Но детям особо нравится, когда предметы для «исследования» натуральные. Лимон и яблоко попробовали - они кислые, конфета и сахар - сладкие, орех и камешек ощупали - твердые, снег и лед - холодные. «Чем отличаются?» используются как парные картинки, так и изображения разных предметов: грузовик и такси, дуб и береза, ведро и бочка и другие. «Послушай и ответь»помимо формирования словаря имен прилагательных, она развивает у детей мышление, слуховое внимание, память, например: муравей, тыква, слон, пуговица, желудь - назвать маленькое, назвать большое. «Что лишнее?», «Хлопни в ладоши, если услышишь живое и маленькое», «Чем похожи по цвету, вкусу, величине?» (названия позволяют опустить описание использования игр) формируют у детей умения сравнивать и находить существенные признаки предметов, дифференцировать их качества. Эти умения являются необходимым условием использования слов-определений в точном значении.

С целью определения результативности данного опыта работы в конце 2019/2020 учебного года было исследовано состояние атрибутивной лексики у детей старшего дошкольного возраста с ОНР.

Анализ результатов показал увеличение уровня всех критериев исследования: объем активного словаря вырос на 20\%, объем пассивного словаря - на 11\%, показатель состояния процессов группировки слов увеличился на 33\%, показатель подбора антонимов на 32\%, показатель сформированности навыков образования сравнительной степени прилагательных на 37\%, относительных прилагательных на 48\%. 
В речи детей появились слова-определения, что, несомненно, сделало ее более богатой и информативной. В большинстве своем не вызывает трудностей у воспитанников подбор признаков к предметам, подбор антонимов к заданным прилагательным. Дети овладели навыками словообразования относительных прилагательных и сравнительной степени прилагательных, активно употребляют данные навыки при характеристике предметов. А приобретенные в процессе игр умения анализировать, устанавливать сходства и различия, находить существенные признаки предметов помогают понимать и использовать многие имена прилагательные точно и правильно. Кроме того, данная система дидактических игр позволила сложным и порой малоинтересным упражнениям стать для детей увлекательным занятием.

Таким образом, использование описанной выше системы дидактических игр является эффективным средством формирования словаря имен прилагательных у детей старшего дошкольного возраста с ОНР, позволяющим увеличить объём словаря, сократить разницу между активным и пассивным словарем, устранить неточности и однотипность употребляемых слов. Все это, несомненно, способствует развитию коммуникативной компетенции детей.

Перспективами развития описанного опыта является дальнейшая разработка игрового дидактического материала для детей старшего дошкольного возраста с ОНР, направленного на формирование лексической системности, на формирование умений подбирать синонимы, образовывать притяжательные прилагательные.

Опыт может быть рекомендован учителям-дефектологам учреждений дошкольного образования. Был представлен в ГУО «Ясли-сад № 19 г. Мозыря» при проведении мастер-класса, при проведении открытых занятий в рамках недели «Педагогического мастерства», неоднократно при проведении открытых занятий для студентов УО «Мозырский государственный педагогический университет им. И. Шамякина».

\section{Список литературы}

1. Лалаева Р.И., Серебрякова Н.В. Коррекция общего недоразвития речи у дошкольников (формирование лексики и грамматического строя) / Р. И. Лалаева, Н. В. Серебрякова. - Санкт-Петербург: Союз, 1999. - 160 с.

2. Лалаева, Р. И. Методика психолингвистического исследования нарушений речи: учебно-методическое пособие / Р. И. Лалаева. - СанктПетербург: Наука-Питер, 2006. - 102 с. 
3. Кислякова, Ю.Н. Программа для специальных дошкольных учреждений: Воспитание и обучение детей с тяжелыми нарушениями речи / Ю.Н. Кислякова, Л.Н. Мороз. - Минск: Национальный институт образования, 2007. - 280 c.

4. Кислякова, Ю.Н. Развитие речи: занимательные игры и упражнения: наглядное пособие для педагогов учреждений образования, реализующих образовательную программу специального образования на уровне дошкольного образования / Ю.Н. Кислякова, М.В. Былино. - Минск: Народная асвета, 2014. - $111 \mathrm{c}$.

5. Ткаченко, Т.А. Логопедические упражнения/ Т.А. Ткаченко. Москва: Эксмо 2005. - 224 с.

(C) 3.М.Загоранская,2020 